\title{
Research on Audit Risk Issues in Accounting Information System
}

\author{
Xianchang Liu \\ School of Economics, Fujian Normal University, Fuzhou 350007, China
}

Key words: accounting information system, audit risks, risk prevention.

\begin{abstract}
Under the contemporary information-based big data model, the continuous development of Internet information basically popularize the accounting information system among enterprises, which derives the audit of accounting information system different from the traditional manual audit. However, due to the hidden nature, uncontrollability, stringiness and other characteristics of audit risks of the accounting information system, auditors find it easy to fail to identify the audit risks of accounting data, internal control and audit environment in the accounting information system in a timely manner when implementing the accounting information system audit, which results in the audit misstatement. Based on the audit risk problems of the accounting information system in the above three aspects, this paper puts forward to ensure the real and complete accounting data, efficient and effective internal control and guarantee the operation environment of the accounting information system so as to reduce the audit risks of the accounting information system and ensure the authenticity and integrity of the authentication business.
\end{abstract}

\section{Accounting information system and audit risks}

\subsection{Accounting information system}

Accounting information system is a value-oriented information system, it is an information system that puts forward information demand from the angle of reflecting and supervising the value movement in its enterprise, and in China, if the main accounting data are generated by the computer automatically, then there exists the accounting information system audit. The accounting information system audit includes the collection, storage, processing, transmission and output of financial data, and its audit objectives focus on the legitimacy, security and integrity of the accounting information system. While the accounting information system audit has basically the same procedures as those of the traditional manual financial audit.

\subsection{Audit risks}

In the research field of auditing, no consensus has been reached internationally on the definition of audit risks, but audit risk is highly affirmed internationally in the process of auditing. Audit risk can be distinguished from narrow sense and broad sense, audit risk in the narrow sense is the risk arising from the auditor's inappropriate opinions on the level of corporate financial statements; in the broad sense, audit risk is produced by the management of the audited enterprise, which is only aggravated by the audit staff and the certified public accountant. 


\section{Audit risks in the accounting information system}

\subsection{Audit risks of accounting data}

In the era of data-based accounting information, especially with the development of highly integrated ERP information system, traditional accounting information is gradually replaced by electronic accounting information. In the accounting information system of an enterprise, accountants only need to confirm the input and output of electronic data, and the intermediate processing link is completed independently by the information system. The accounting information is no longer presented to the auditor in the paper form, but is converted into electronic data stored on hard drives or other magnetic media. These electronic data can easily be illegally modified, abused or deleted through the firewall of the information system without leaving traces. It is difficult for the auditor to judge whether the electronic data provided by the audited unit is tampered with the naked eye, which undoubtedly increases the audit risk. Therefore, as the accounting information becomes electronic data, adding a layer of gauze to the audit personnel, it will undoubtedly increase the audit risk.

\subsection{Audit risks in internal control}

In the accounting information system, the internal control of the enterprise is controlled by the accounting information system, the distribution of incompatible duties of posts is relatively centralized in accounting information system, the audited unit separates the incompatible posts of the audited unit by dividing the responsibilities of different operators, setting different operator passwords and giving different responsibilities to different sub-modules of accounting information system at the same time. This control measure relies on the audited unit's accounting information system in the form of a program. In this case, once the password of the operator has been leaked or the audit unit has unintentionally or intentionally given the employee the right to operate across authority, the internal control system of the audited unit will exist in name only, but it will directly affect the authenticity of the output data of the accounting information system when the internal control is imperfect or it becomes not effective. This leaves a loophole to exploit for fraudulent behaviors and brings the audit risk. To sum up, accounting information system is an integrated information system, accounting users can use the information in the information system to make more reasonable decisions, so it is very important to ensure the authenticity of accounting information. However, since China's accounting information system starts late, its development is not mature enough and the quality of accounting information still needs to be improved, so it is especially necessary to strengthen the audit strength of accounting information system.

\subsection{Audit risks in the audit environment}

Since the development of modern communication computer technology brings the risk of different manual audits to computer audit, accounting information system is vulnerable to hackers and viruses, and this behavior will cause huge losses to the audited unit. As developers of accounting information system pay attention to computer technology itself, the general accounting information system can not accurately meet the needs of the actual work of the audited unit. For example, in the accounting information system, the designed procedures are interdependent, and when the internal control system is flawed, the audited unit cannot be adjusted in a timely and flexible manner like manual audit. Therefore, when the accounting information system itself is very likely to have system defects, for instance, the design of software system data control is not strict, the log record is not complete, there is a lack of recovery measures or data backup plans for the failure of system operation, the system does not 
reserve an audit interface, all of these will bring audit risks to the auditors, and besides, the risks are usually hidden, and it is difficult for auditors to judge by the naked eye. Network transmission and data storage will cause huge concealment errors of electronic data, which will be very difficult to eliminate even if the internal control operation of the audited unit is effective. Such situation appears in the accounting information system with a high degree of integration, and there exist common risks of data sharing audit.

\section{The prevention of audit risks in the accounting information system}

\subsection{Ensure the integrity and authenticity of accounting data}

In order to ensure the integrity and authenticity of electronic data, auditors should strengthen the audit of accounting information system in advance and afterwards at the time of data acquisition; utilize multiple aspects and multiple angles of audits such as initial data, period data and data output of the accounting information system to avoid the audited unit from altering the accounting information. The auditor confirms that the electronic data is within the audit time range by reserving the auditing interface; record the number of printed statements through the reverse posting of account, settlement function of the accounting information system to prevent tampering with audit. When ensuring the integrity of electronic data, it is suggested use automatic transfer function from the audit unit or to scan important original documents. The auditor should also improve the auditing skills and methods to provide a reasonable guarantee for ensuring the truthfulness and completeness of the accounting electronic data provided by the audited unit. In the implementation of the audit process, a variety of audit methods are used in combination, such as manual audit, sequential check and reverse check to audit whether there are concealed and tampered signatures, etc., different accounting information systems used by the audited unit will undoubtedly increase the audit risk. Auditing staff should design targeted auditing inspection procedures, for instance, check the financial statement formula of the audited unit, and check whether the account of each subsystem under the accounting information system is consistent with other accounts and accountable according to facts.

\subsection{Ensure the safe and effective operation of internal control}

In order to prevent inappropriate human intervention and ensure the effective operation of internal control in accounting information system, the risk assessment procedures for internal control should be strengthened to identify the weaknesses in the internal control of the accounting information system, further perfect the internal control of the audited unit and reduce the audit risk. The system administrator divides the labor for accountants in different positions, give them different accounting authorities and operation passwords, accounting personnel can enter the accounting information system for accounting operation only after entering the correct passwords and passing the identification and verification. Operators should regularly change passwords to prevent the leakage of passwords. Auditors are concerned about whether there exists the unauthorized log-in of accounting information systems. It is necessary to focus on controlling the authority operation across areas of responsibility, and ensure the independent division of the functions of various departments; strengthen the technical application of internal control, for example, strengthen the audit of operation logs of accounting information system, check whether the output, processing and output of electronic data is authorized. 


\subsection{Guarantee the operating environment of accounting information system}

Accounting information systems need to be protected in an increasingly open information technology environment. The application of information encryption algorithms and the security protection of external networks should be strengthened, which are the powerful measures to fundamentally prevent the accounting information system from hackers and viruses attack. When carrying out the audit work, it is required to pay attention to the hardware, audit the supplier's production qualifications and product situation; especially for the application of hardware devices, it is suggested to choose the most reliable products for servers and switches. Besides hardware, it is essential to attach importance to software control. In addition, authorization is required to allow staff to access to the operating room, mainly to restrict their bad behaviors and prevent the loss of information. At the same time, an audit interface can be reserved in the accounting information system, which can achieve dynamic pre-event and intra-event audit without disturbing the daily work of the audited unit, and what is more important is that it can prevent the audited unit from audit risk by modifying the accounting data.

\section{Conclusion}

The great development of Internet and the progress of electronic information technology results in the deepening informatization of the accounting industry. As there exist audit risks in the accounting information system, we need to put forward countermeasures from accounting data, internal control, audit environment and other aspects so as to achieve the aim of reducing audit risks of accounting information system and promote the steady and healthy development of the whole industry better.

\section{References}

[1] Hou Yangyang. Discussion on Auditing Problems of Accounting Information System [J].Business, 2015, (23).

[2] Tang Sixin. Research on Theoretical Structure of Accounting Information System [J]. Journal of Nanjing Audit University, 2012, (3).

[3] Zhang Chi. Discussion on the Challenge and Reform of Accounting Information System Development by Information Technology [J]. Business, 2016, (5).

[4] Jiang Huimin.Discussion on Auditing Problems of Accounting Information System [J].Chinese and Foreign Entrepreneurs, 2016, (11).

[5] Su Qinglang. Analysis of Security Countermeasures of Network Accounting Information System [J]. Science and Technology, 2017, (5).

[6] Qiu Mengyao. Analysis of Internal Control of Accounting Information System [J]. China Management Informationization, 2017, (3).

[7] Qiao Hang. On the Development Trend of Accounting Information System [J]. Journal of Chifeng University (Natural Science Edition), 2016, (4). 